\title{
The outcome of acute schistosomiasis infection in adult mice with postnatal exposure to maternal malnutrition
}

\author{
Christiane Leal Corrêa', Patrícia Cristina Lisboa² ${ }^{2}$ Elaine de Oliveira² ${ }^{2}$ Egberto Gaspar de Moura², \\ Regina Maria Figueiredo de Oliveira ${ }^{1}$, Adriana Cardoso Gomes ${ }^{1}$, José Roberto Machado-Silva1/+ \\ ${ }^{1}$ Laboratório de Helmintologia Romero Lascasas Porto, Departamento de Microbiologia, Imunologia e Parasitologia, \\ Faculdade de Ciências Médicas ${ }^{2}$ Laboratório de Fisiologia Endócrina, Departamento de Ciências Fisiológicas, \\ Instituto de Biologia Roberto Alcântara Gomes, Universidade do Estado do Rio de Janeiro, Rio de Janeiro, RJ, Brasil
}

\begin{abstract}
Maternal malnutrition during the lactation period in early development may have long-term programming effects on adult offspring. We evaluated the combined effects of parasitological behaviour and histopathological features and malnutrition during lactation. Lactating mice and their pups were divided into a control group (fed a normal diet of $23 \%$ protein), a protein-restricted group (PR) (fed a diet containing $8 \%$ protein) and a caloric-restricted group (CR) (fed according to the PR group intake). At the age of 60 days, the offspring were infected with Schistosoma mansoni cercariae and killed at nine weeks post-infection. Food intake, body and liver masses, leptinaemia, corticosteronaemia, collagen morphometry and neogenesis and the cellular composition of liver granulomas were studied. PR offspring showed reduced weight gain and hypophagia, whereas CR offspring became overweight and developed hyperphagia. The prepatent period was longer (45 days) in both programmed offspring as compared to controls (40 days). The PR-infected group had higher faecal and intestinal egg output and increased liver damage. The CR-infected group showed a lower number of liver granulomas, increased collagen neogenesis and a higher frequency of binucleate hepatocytes, suggesting a better modulation of the inflammatory response and increased liver regeneration. Taken together, our findings suggest that neonatal malnutrition of offspring during lactation affects the outcome of schistosomiasis in mice.
\end{abstract}

Key words: Schistosoma mansoni - programming - lactation - host-parasite relationship - parasitology - histopathology

In developing countries, both malnutrition and parasite infections remain major public health concerns (WHO 2005, Atinmo et al. 2009). Epidemiological data have shown detrimental effects of malnutrition and infection on health, cognition and behaviour in preschool-aged children affected with concurrent morbidities (Stephenson et al. 2000, Crompton \& Nesheim 2002, Muniz et al. 2002, Hughes \& Kelly 2006, Casapía et al. 2007, Jardim-Botelho et al. 2008). Previous studies in Northeastern Brazil have demonstrated that schistosomiasis mansoni and malnutrition often overlap (Coutinho et al. 1997) and the infection exerts a negative effect on the anthropometric status of school-aged children, even during low-moderate levels of infection (Parraga et al. 1996, Assis et al. 1998).

Epidemiological, clinical and experimental data suggest that intrauterine undernutrition is closely associated with adulthood obesity and is related to detrimental metabolic sequelae (Godfrey \& Barker 2000, Vickers et al. 2001), which has given rise to the concept of "developmental origins of health and disease". This association is referred to as metabolic programming, which is defined as a biological phenomenon that determines the relationship between physical and chemical stimuli in critical periods of early life, such as gestation and/

+Corresponding author: machado@uerj.br

Received 29 January 2011

Accepted 24 May 2011 or lactation, with future functional status (de Moura et al. 2008). Among children, protein-energy malnutrition is the most prevalent nutritional disorder and often occurs during gestation, lactation and the first two years of life (Desai et al. 2000). In fact, experimental data have reported that maternal malnutrition during the critical period of lactation may have deleterious effects during the adult life of the offspring, even if the animal had free access to a normal diet after weaning (Passos et al. 2000, 2004, Vicente et al. 2004, Fagundes et al. 2007, 2009, Moura et al. 2007, Lisboa et al. 2008).

Nutritional changes associated with lactation influence the host-parasite relationship of gastrointestinal roundworms Heligmosomoides polygyrus (Kristan 2002) and Nippostrongylus brasiliensis in the rat model (Normanton et al. 2007). Previous experimental studies have established that protein restriction post-weaning impairs the outcome of experimental schistosomiasis mansoni in adult mice (Akpom 1982, Rocha 1982, Coutinho et al. 1991, 2003, Ferreira \& Coutinho 1999). However, no study has explored the joint effects of postnatal malnutrition on the outcome of schistosomiasis. Therefore, it is important to determine whether malnutrition during the lactation period only can affect adult offspring infected by Schistosoma mansoni. The present study used a murine model of nutritional programming in which lactating mice were submitted to a protein-restricted (PR) or caloric-restricted (CR) diet throughout lactation. Weaning pups received a normal diet. The effects of acute schistosomiasis in terms of weight gain, food intake, visceral fat mass, egg production in the stool, tissue egg count, worm burden and histopathology were evaluated. 


\section{MATERIALS AND METHODS}

Swiss Webster mice were housed in polypropylene boxes $(40 \times 33 \mathrm{~cm})$ in a room with controlled temperature $\left(25 \pm 1^{\circ} \mathrm{C}\right)$ and humidity $(60 \pm 10 \%)$ and an artificial light/dark cycle (lights on from 07:00 am-19:00 pm). Two three-month-old, virgin, female mice were housed together with a male mouse for mating. After mating, each female was placed in an individual cage with free access to water and food until delivery.

Model of programming by maternal malnutrition during lactation - Mouse dams were randomly assigned to one of the following three groups: (i) control (C) (n $=10$ ), allowed free access to a standard laboratory diet (23\% protein), (ii) PR ( $\mathrm{n}=10)$, allowed free access to an isoenergetic, low-protein diet ( $8 \%$ protein) and (iii) $\mathrm{CR}$ $(\mathrm{n}=10)$, received a standard laboratory diet in restricted quantities that were calculated according to the mean ingestion of the PR group (a pair feed group). Twenty-four hours after birth, litters were culled to six male pups per dam to maximise lactation performance.

Table I shows the composition of the diets (Reeves et al. 1993). The PR diet was produced in our laboratory, using the standard commercial diet for rodents (NuvilabNuvital Nutrientes SA, PR, Brazil) by replacing parts of the protein with cornstarch (Lisboa et al. 2003, de Moura et al. 2007, Fagundes et al. 2009). The amount of cornstarch that was added compensated for the decrease in energy content due to protein reduction. Vitamin and mineral mixtures were formulated according to the AIN-93G recommendation for rodent diets (Reeves et al. 1993).

Neonatal malnutrition began at the time of the pup's birth (day 0) and ended at weaning (21 days). After weaning, offspring were fed a standard diet $(23 \%$ protein) until they reached 120 days of age. We used two offspring randomly chosen from each litter per group (total of 20 pups/dam group).

Nutritional evaluation - Body weight and food consumption were monitored every four days from the time of weaning until the pups were 120 days old. The visceral fat mass (VFM) (mesenteric, epididymal and retroperitoneal adipose tissue) was excised and weighed for the evaluation of central adiposity. Fat mass was determined by carcass analysis as reported previously (Fagundes et al. 2007).

Blood samples were centrifuged $\left(1,500 \mathrm{~g} / 20 \mathrm{~min} / 4^{\circ} \mathrm{C}\right)$ to obtain serum, which was frozen $\left(-20^{\circ} \mathrm{C}\right)$ until assaying. Leptinaemia was determined with a specific radioimmunoassay kit (Linco Research Inc, Missouri, USA) that measures both rat and mouse leptin with a range of detection from $0.5-50 \mathrm{ng} / \mathrm{mL}$. Measurements were performed in a single assay with an intra-assay variation of $2.9 \%$. Corticosteronaemia was measured using a specific commercial RIA kit (ICN Biomedicals Inc, Aurora, $\mathrm{OH}, \mathrm{USA}$ ) with an assay sensitivity of $50 \mathrm{ng} / \mathrm{mL}$ and an intra assay variation coefficient of $7 \%$.

Parasites and experimental infection protocol - An active life cycle of $S$. mansoni has been maintained at the Malacology Laboratory (Oswaldo Cruz Institute, Rio de Janeiro, Brazil) since 1985, using Biomphalaria glabrata snails and mice as intermediate and definitive hosts, respectively. Procedures for experimental infections have
TABLE I

Composition of the diets

Control diet ${ }^{a} \quad$ Low-protein $\operatorname{diet}^{b}$ $(\mathrm{g} / \mathrm{Kg}) \quad(\mathrm{g} / \mathrm{Kg})$

\begin{tabular}{lcc}
\hline Ingredients & & \\
Soybean + wheat & 230.0 & 80.0 \\
Cornstarch & 676.0 & 826.0 \\
Soybean oil & 50.0 & 50.0 \\
Vitamin mix & & 4.0 \\
Mineral mix $^{c}$ & 4.0 & 40.0 \\
Macronutrient composition (\%) & 40.0 & \\
Total energy (kj/kg) & $17,038.7$ & $17,038.7$ \\
Protein & 23 & 8 \\
Carbohydrate & 66 & 81 \\
Fat & 11 & 11 \\
\hline
\end{tabular}

$a$ : standard diet for rats (Nuvilab-Nuvital Nutrientes SA, PR, Brazil); $b$ : the low-protein diet was prepared in our laboratory using the control diet and replacing part of its protein with cornstarch. The amount of the latter ingredient was calculated to make up for the decrease in energy content due to protein reduction; $c$ : vitamin and mineral mixtures were formulated to meet the AIN-93G recommendation for rodent diet and contain the recommended amount of iodine (Reeves et al. 1993).

been described previously (Freire et al. 2003). At two months old, mouse pups were divided in six groups, according to diet: uninfected $\mathrm{C}$, uninfected PR, uninfected $\mathrm{CR}$, infected C (IC), infected PR (IPR) and infected CR (ICR). Infections consisted of $50 \mathrm{~S}$. mansoni cercariae (BH strain) and were administered percutaenously. Ten animals were included in each group.

Parasitological studies - Faecal samples from infected groups were microscopically examined after six weeks to confirm that an infection was established. The mean number of eggs per gram was estimated from two fresh faecal samples, collected at two day intervals from six weeks until the time of euthanasia using the KatoKatz smear technique (Katz et al. 1972). The pre-patent period was defined as the time when the first faecal eggs were found (Martinez et al. 2003). Infected mice were euthanized by cervical dislocation at $24 \mathrm{~h}$ after the last faecal examination. Parasite burden (infectivity) was calculated as the percentage of cercariae recovered from the portal system and mesenteric veins that had matured into adult worms (Freire et al. 2003).

Tissue egg load - To enumerate tissue eggs, the small intestine was digested in $4 \%$ potassium hydroxide at $56^{\circ} \mathrm{C}$ and centrifuged $(900 \mathrm{~g})$ for $5 \mathrm{~min}$ (Neves et al. 2007b). Aliquots of $100 \mu \mathrm{L}$ were placed in duplicate on a glass slide and counted by light microscopy (100X) (Martinez et al. 2003).

Oogram pattern - Two segments $(1 \mathrm{~cm}$ each) from different sites in the small intestine (proximal and distal sections) and large intestine of infected animals were 
TABLE II

Biometrical parameters and serum leptin in schistosomiasis-infected adult male mice whose mothers were fed with control (C), caloric-restricted (CR) or protein-restricted (PR) diet during lactation

\begin{tabular}{lcccccc}
\hline & \multicolumn{5}{c}{ Groups } \\
\cline { 2 - 7 } & $\begin{array}{c}\mathrm{C} \\
\text { Uninfected }\end{array}$ & $\begin{array}{c}\text { CR } \\
\text { Uninfected }\end{array}$ & $\begin{array}{c}\text { PR } \\
\text { Uninfected }\end{array}$ & $\begin{array}{c}\mathrm{C} \\
\text { Infected }\end{array}$ & $\begin{array}{c}\text { CR } \\
\text { Infected }\end{array}$ & $\begin{array}{c}\text { PR } \\
\text { Infected }\end{array}$ \\
\hline Food intake (g) & $9.30 \pm 0.32$ & $10.89 \pm 0.30^{b}$ & $6.59 \pm 0.24^{b, c}$ & $9.01 \pm 0.33$ & $9.70 \pm 0.44^{a}$ & $6.01 \pm 0.39^{b, c}$ \\
Body weight (g) & $33.80 \pm 1.29$ & $38.80 \pm 0.55^{b}$ & $27.30 \pm 1.12^{c}$ & $31.80 \pm 1.29$ & $35.20 \pm 0.62^{a, b}$ & $27.30 \pm 1.12^{b, c}$ \\
Liver weight (g) & $1.62 \pm 0.04$ & $1.60 \pm 0.03$ & $1.61 \pm 0.05$ & $2.14 \pm 0.06^{a}$ & $2.11 \pm 0.07^{a}$ & $1.87 \pm 0.11^{a}$ \\
Visceral fat mass & $1.70 \pm 0.18$ & $2.13 \pm 0.40^{c}$ & $0.993 \pm 0.17$ & $1.46 \pm 0.22$ & $1.28 \pm 0.19^{a}$ & $1.48 \pm 0.31$ \\
Fat mass & $8.30 \pm 0.64$ & $12.07 \pm 1.06^{b}$ & $14.13 \pm 1.52^{b}$ & $8.41 \pm 0.81$ & $5.56 \pm 0.28^{a}$ & $8.62 \pm 0.51^{a}$ \\
Leptin & $3.21 \pm 0.43$ & $6.92 \pm 1.47^{b}$ & $4.57 \pm 1.37$ & $3.35 \pm 0.77$ & $1.99 \pm 0.35^{a}$ & $4.24 \pm 0.58$ \\
Corticosterone & $54.1 \pm 8.0$ & $69.2 \pm 8.9$ & $62.1 \pm 13.1$ & $32.8 \pm 6.3$ & $90.3 \pm 18.8^{a}$ & $65.2 \pm 13.5$ \\
\hline
\end{tabular}

$a$ : infected vs. uninfected; $b$ : vs. C ; $c$ : vs. CR or PR. Data presented as means \pm standard error of the mean (significant difference: $\mathrm{p}<0.05)$.

removed (Machado e Silva et al. 1991). Segments were opened, washed and crushed between two glass slides to obtain a thin preparation. The percentage of immature, mature and dead $S$. mansoni eggs was determined by conventional light microscopy (Freire et al. 2003).

Histopathology and morphometry of S. mansoni granulomas - Liver, intestine and VFM were excised and weighed. Liver samples from all mice were fixed in $10 \%$ buffered formalin and processed for routine histopathological analysis. Five-micrometre sections were stained with haematoxylin and eosin, Masson's trichrome or Picrosirius for collagen plus polarisation microscopy (Lennert \& Parwaresch 1978). Periovular reactions in the liver were classified according to Li Hsü et al. (1972) as modified by Lenzi et al. (1998). Reactions were classified as the pre-granulomatous stage (weakly reactive or nonreactive and exudative stages) or the granulomatous stage (exudative-productive, productive and involutional granulomas). The area, perimeter and major and minor diameter of individual granulomas were measured by computed image analysis (Image Pro-Plus Media Cybernetics, US), as described previously (Costa-Silva et al. 2002).

Statistical analysis - Results are expressed as mean values \pm standard error of the mean. The GraphPad Prism 4 programme (GraphPad Software, Inc, La Jolla, CA, USA) was used for statistical analyses and graphics. Body weight, food intake and parasitological results were analysed by one-way analysis of variance and NewmanKeuls multiple comparison tests. Other experimental data (infected vs. uninfected group) were analysed by Student's unpaired $t$ test and differences were considered significant at $\mathrm{p}<0.05$.

Ethics - The use of the animals according to our experimental design was approved by the Animal Care and Use Committee of the Biology Institute of the State University of Rio de Janeiro (CEUA/232/2008), which based its analysis on the principles adopted and promulgated by Brazilian Law 11.794/2008 (Marques et al. 2009).

\section{RESULTS}

Effect of maternal malnutrition - At the end of lactation, mothers from the CR $(30 \pm 1.99 \mathrm{~g})$ and PR $(24.05 \pm$ $0.38 \mathrm{~g})$ groups had significantly $(\mathrm{p}<0.0001)$ lower body mass compared to the $\mathrm{C}$ group $(42.55 \pm 2.01 \mathrm{~g})$. There was also a significant difference in the weight of their offspring (C: $12.5 \pm 0.18 \mathrm{~g}$; CR: $11.3 \pm 0.10 \mathrm{~g}$; PR: $5.9 \pm 0.12 \mathrm{~g}$ ).

At 120 -days-old (Table II), food intake was $17 \%$ higher in uninfected-CR pups compared to C pups $(\mathrm{p}<0.01)$, but decreased in uninfected-PR pups $(-29 \%$ vs. C; $-39 \%$ vs. $\mathrm{CR}, \mathrm{p}<0.001)$. In uninfected animals, we observed that the PR offspring had a $19 \%$ reduction in body mass compared to $\mathrm{C}$ pups $(\mathrm{p}<0.01)$, whereas the CR offspring had a $15 \%$ greater body mass compared to $\mathrm{C}$ pups ( $\mathrm{p}<$ 0.05 ) and a 53\% increase in VFM compared to the PR pups $(\mathrm{p}<0.05)$. Compared to the C pups, the total body fat was $45 \%$ and $70 \%$ greater in CR $(p<0.05)$ and PR ( $p<0.001$ ) offspring, respectively, but only the CR offspring presented hyperleptinaemia ( $+115 \%$ vs. C).

Serum corticosterone and liver weight of uninfected $\mathrm{C}, \mathrm{CR}$ and PR offspring was not significantly different (Table III).

Effect of infection - At the time of sacrifice ( 9 weeks post-infection), the infection resulted in a lower body mass $(-9 \%, \mathrm{p}<0.001)$, lower food intake $(-11 \%, \mathrm{p}<$ $0.05)$ and lower VFM $(-40 \%, p<0.05)$ only in the infected-CR group compared to its respective uninfected group. The infection did not alter body mass, food intake or VFM in the PR group.

The IPR and ICR groups had a $39 \%$ and $54 \%$ decrease, respectively, in body fat mass compared to the $\mathrm{CR}$ and $\mathrm{PR}$ groups $(p<0.001)$. The ICR group showed lower levels of serum leptin (CR vs. ICR: -71\%). As depicted in Table II, the IRC offspring showed higher serum corticosterone $(+175 \%, \mathrm{p}<0.05)$ compared to the IC offspring.

The infection was associated with higher liver weight of all offspring compared to their respective $\mathrm{C}$ group (C vs. IC: $+32 \%$; CR vs. ICR: $+32 \%, \mathrm{p}<0.0001$; PR vs. IPR: $+16 \%, \mathrm{p}<0.05$ ) (Table II). 
TABLE III

Parasitological parameters in schistosomiasis-infected adult male mice whose mothers were fed with control (C), caloric-restricted (CR) or protein-restricted (PR) diet during lactation

\begin{tabular}{lcccc}
\hline & \multicolumn{3}{c}{ Groups } \\
\cline { 2 - 5 } & $\mathrm{C}$ & $\mathrm{CR}$ & $\mathrm{PR}$ & $\mathrm{p}$ values \\
\hline Pre-patent period (days) & $40 \pm 2$ & $45 \pm 2$ & $45 \pm 2$ & $0.0010^{a}$ \\
Faecal egg count (total) & $271.0 \pm 69.0$ & $172.0 \pm 45.0$ & $5424.0 \pm 114.0$ & $0.0140^{a}$ \\
Tissue egg load/section & & & \\
$\quad$ Proximal & $1172.0 \pm 290.0$ & $319.0 \pm 120.0$ & $1130.0 \pm 454.0$ & 0.1227 \\
Distal & $1755.0 \pm 286.0$ & $962.0 \pm 494.0$ & $2029.0 \pm 440.0$ & 0.1923 \\
Cecum & $733.0 \pm 246.0$ & $183.0 \pm 63.0$ & $762.0 \pm 177.0$ & $0.0515^{a}$ \\
Egg developmental stages (oogram) & & & & \\
Mature & $39.0 \pm 6.0$ & $9.0 \pm 1.0$ & $62.0 \pm 16.0$ & $0.0123^{a}$ \\
Immature & $221.0 \pm 32.0$ & $77.0 \pm 15.0$ & $300.0 \pm 48.0$ & $0.0004^{a}$ \\
Dead & $9.0 \pm 2.0$ & $3.0 \pm 1.0$ & $26.0 \pm 7.0$ & $0.0058^{a}$ \\
Infectivity & 50 & 52 & 77 & 0.4672 \\
\hline
\end{tabular}

$a$ : significant difference $(\mathrm{p}<0.05)$. Data presented as means \pm standard error of the mean.

Parasitological studies - As shown in Table III, schistosome eggs were first detectable in IC offspring and then simultaneously in ICR and IPR. IPR offspring eliminated a greater number of faecal eggs than the IC ( $211 \%$ increase) or ICR (600\% increase) offspring. The infectivity and tissue egg load in the proximal and distal sections of the small intestine were not statistically different, despite differences in maternal diets. In the caecum section, the egg count was decreased by $75 \%$ in the ICR offspring compared to the IC offspring. Oogram evaluation revealed that the ICR offspring had a $65 \%$ decrease in the number of immature eggs compared to the IC offspring whereas the IPR offspring had a $288 \%$ increase compared to the ICR offspring. We observed a $561 \%$ increase in the number of mature eggs in the IPR offspring compared to the ICR offspring, as well as an increase in the number of dead eggs $(167 \%$ increase vs. IC and $803 \%$ increase vs. ICR).

Histopathology and morphometry - Concerning the programming effect, the PR offspring exhibited normal liver structures in terms of aspects and trabecular architecture. However, CR offspring showed microvesicular steatosis.

The qualitative cellular composition of liver granulomas was similar among offspring, with accumulations of inflammatory cells (macrophages, eosinophils and lymphocytes) differing according to the type of granuloma evolution. In exudative granulomas, there were macrophages, eosinophils, neutrophils and lymphocytes (Table IV). However, exudative-productive granulomas were predominantly composed of fibroblasts and macrophages rather than lymphocytes, plasma cells and eosinophils (Table IV).

Morphometric analysis (Table IV) showed that mean area of exudative granulomas was $86 \%$ smaller in the ICR offspring and $82 \%$ larger in IPR offspring. However, exudative-productive granulomas were larger in both IPR ( $81 \%$ increase) and ICR (63\% increase) offspring compared to IC offspring. Collagen neogenesis was observed in some exudative granulomas from IC $(14.93 \%)$, IPR (20.33\%) and ICR (25.53\%) groups.

Histopathological examination of C and PR offspring showed normal portal space and liver parenchyma (in terms of hepatocytes and sinusoids arrangement) (Figs 1A, 2A).

Regarding IC offspring, eggs elicited both monocyte and polymorphonuclear leucocyte migration (Fig. 1B). Fibrotic changes within the granulomas were highlighted by Masson's trichrome stain (data not shown). Photomicrographs of liver sections showed exudative granulomas with a central egg surrounded by a prominent disarranged cellular composition in the outer layer (Fig. 1C).

IPR offspring showed leucocyte infiltrate that was not associated with the presence of a schistosomal granuloma (Fig. 2B). Schistosome eggs elicited an intense acute inflammatory reaction that was characteristic of a pre-granulomatous type granuloma (data not shown) and exudative peri-ovular lesions surrounding a central schistosomal egg (Fig. 2C). At the cellular level, PR offspring presented pyknosis, karyorrhexis and karyolysis (data not shown).

Microvesicular steatosis was observed both in the liver parenchyma (Fig. 3A) and hepatocytes (data not shown) of ICR offspring. Intense leucocyte infiltrate with collagen neogenesis and exudative-productive granuloma with regular external contour was observed (Fig. 3B). Schistosomal granulomas showing a concentric arrangement of reticular fibres (Fig. 3C) and liver regeneration characterised by binucleate hepatocytes were also evident (data not shown).

\section{DISCUSSION}

Lactation is a critical period during the development of mammals and is important in the establishment of programming (Moura et al. 2008). Mice from CR and PR mothers had lower body weight during lactation. After 
TABLE IV

Morphometry and cellular composition of liver granulomas in schistosomiasis-infected adult male mice offspring whose mothers were fed with control (C), caloric-restricted (CR) or protein-restricted (PR) diet during lactation

\begin{tabular}{|c|c|c|c|c|c|c|}
\hline \multirow{3}{*}{ Granulomas } & \multicolumn{6}{|c|}{ Groups } \\
\hline & \multicolumn{2}{|c|}{$\mathrm{C}$} & \multicolumn{2}{|c|}{$\mathrm{CR}$} & \multicolumn{2}{|c|}{ PR } \\
\hline & $E(n=60)$ & $\mathrm{EP}(\mathrm{n}=48)$ & $E(n=08)$ & $\mathrm{EP}(\mathrm{n}=122)$ & $E(n=303)$ & $\mathrm{EP}(\mathrm{n}=63)$ \\
\hline & \multicolumn{6}{|c|}{ Morphometry } \\
\hline Area of granuloma $\left(\mu \mathrm{m}^{2}\right)$ & $42.25 \pm 74.52$ & $59.50 \pm 66.27$ & $5.94 \pm 5.94$ & $96.76 \pm 14.16$ & $76.97 \pm 14.37$ & $108.02 \pm 97.72$ \\
\hline \multirow[t]{2}{*}{ Concentration of collagen (\%) } & - & 14.93 & - & 25.53 & - & 20.33 \\
\hline & \multicolumn{6}{|c|}{ Cellular composition } \\
\hline Macrophages & ++ & ++ & ++ & +++ & + & ++ \\
\hline Epithelioid cells & \pm & + & - & ++ & - & + \\
\hline Giant cells & - & + & - & + & - & - \\
\hline Neutrophils & + & + & + & + & +++ & + \\
\hline Eosinophils & ++ & + & ++ & + & +++ & ++ \\
\hline Mast cells & - & - & - & - & - & - \\
\hline Fibroblasts & \pm & ++ & + & +++ & - & ++ \\
\hline Lymphocytes & ++ & + & ++ & + & ++ & + \\
\hline Plasma cells & \pm & + & \pm & + & - & + \\
\hline Pigment & + & + & + & + & + & + \\
\hline
\end{tabular}

E: exudative granulomas; EP: exudative-productive; grade of intensity: -: negative; \pm : rare; + : few; $++:$ much; +++ : abundant.

weaning, even with an adequate supply of a commercial $\operatorname{diet}(23 \%$ protein) until 120 days of age, the programming of PR offspring resulted in a lower mean body weight, whereas CR programming resulted in overweight offspring. These findings corroborate our previous data using programmed rats (Passos et al. 2000, 2004, Vicente et al. 2004, Fagundes et al. 2007, 2009, Moura et al. 2007, Lisboa et al. 2008). These alterations of body mass can be explained by hypophagia (PR mice) and hyperphagia (CR mice), which is a different conclusion than can be drawn from the rat model, in which food intake was unchanged.

Adult CR offspring exhibited higher total and central fat. This agrees with several studies showing that early malnutrition programmes lead to the development of a thrifty phenotype (Petry et al. 2000, Ozanne \& Hales 2002, Plagemann 2006). Interestingly, PR mice had higher total body fat, as previously detected in PR rats of the same programming model (Fagundes et al. 2007, 2009). Thus, it is possible that the lower body mass of this group is due to a loss of muscle mass. In addition, lower pituitary growth hormone mRNA has been reported in programmed PR offspring (de Moura et al. 2007). Because growth hormone increases protein synthesis in muscle, this finding may also explain the body composition changes of the programmed mice in the present study.

Because leptin is mainly produced by adipose tissue (Ahima 2005), CR offspring showed hyperleptinaemia due to increased adiposity. Hyperleptinaemia and increased food intake in CR mice suggests that these offspring developed central leptin resistance. In fact, rats pro- grammed by maternal CR during lactation are resistant to the anorexigenic effect of leptin (Passos et al. 2004). PR offspring had no significant changes in serum leptin levels. Because these mice displayed a lower food intake, it is possible that they have an increased sensitivity to leptin.

Liver weight was not altered in uninfected CR and PR adult offspring. This was probably because the normal diet offered after weaning was effective at preventing liver weight changes. Histopathologic liver evaluation of uninfected PR offspring revealed that the planned structures were preserved, thereby maintaining the trabecular architecture. However, CR offspring showed microvesicular steatosis, which was probably associated with the higher VFM.

Fatty liver can ultimately lead to inflammation and scarring (Erhuma et al. 2007). Although this condition has multiple causes, fatty liver is a pathological condition in which triglyceride fats accumulate within hepatocytes. Studies in rodents have shown that the nutritional environment contributes to liver injury. Hepatocytes in fatty livers are vulnerable to insults (Carmiel-Haggai et al. 2005). Prolonged feeding of fat-enriched diets induces hepatic steatosis in rodents (Zhang et al. 1999, Rao et al. 2001, Picard et al. 2002, Buettner et al. 2007, Marques et al. 2010). During $S$. mansoni infection, immunocompromised mice fed either a normal diet (Doenhoff et al. 1981) or high-fat chow (Neves et al. 2007a) developed hepatic steatosis. Alternatively, PR throughout gestation and during the first half of lactation has caused higher rates of hepatic steatosis in six-month-old rats (Souza-Mello et al. 2007). 

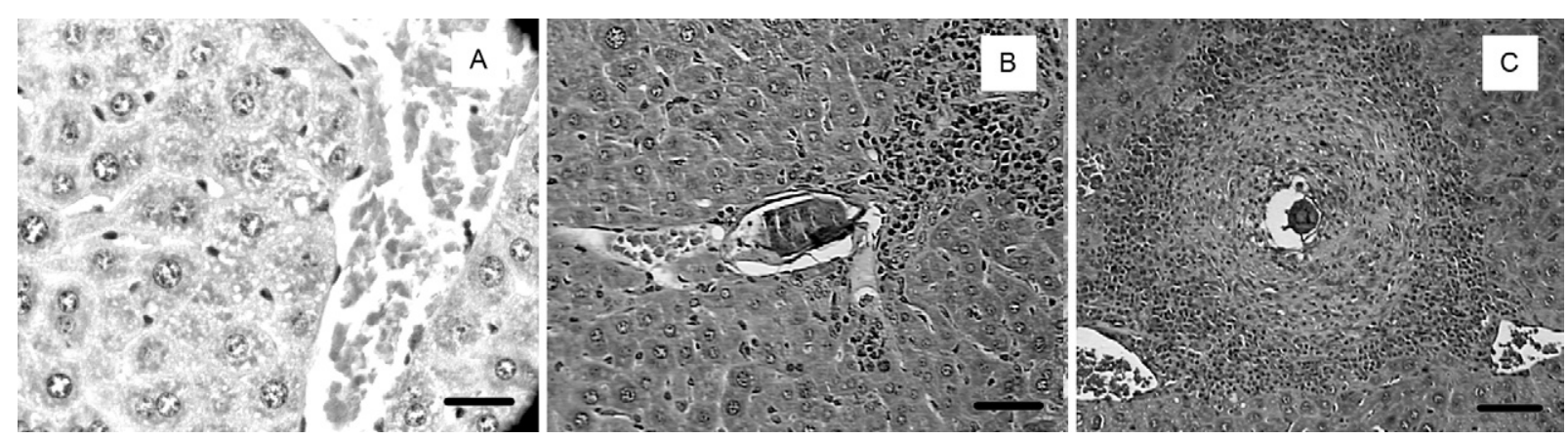

Fig. 1: histopathological analysis of liver sections from adult control offspring. A: portal vein and liver parenchyma are preserved (H\&E) $(\mathrm{Bar}=10 \mu \mathrm{m})$; B: inflammatory cells are surrounding a schistosomal egg within the intravascular space $(\mathrm{H} \& \mathrm{E})(\mathrm{Bar}=10 \mu \mathrm{m})$; $\mathrm{C}$ : exudative granuloma within the portal tract $(\mathrm{H} \& \mathrm{E})(\mathrm{Bar}=20 \mu \mathrm{m})$.
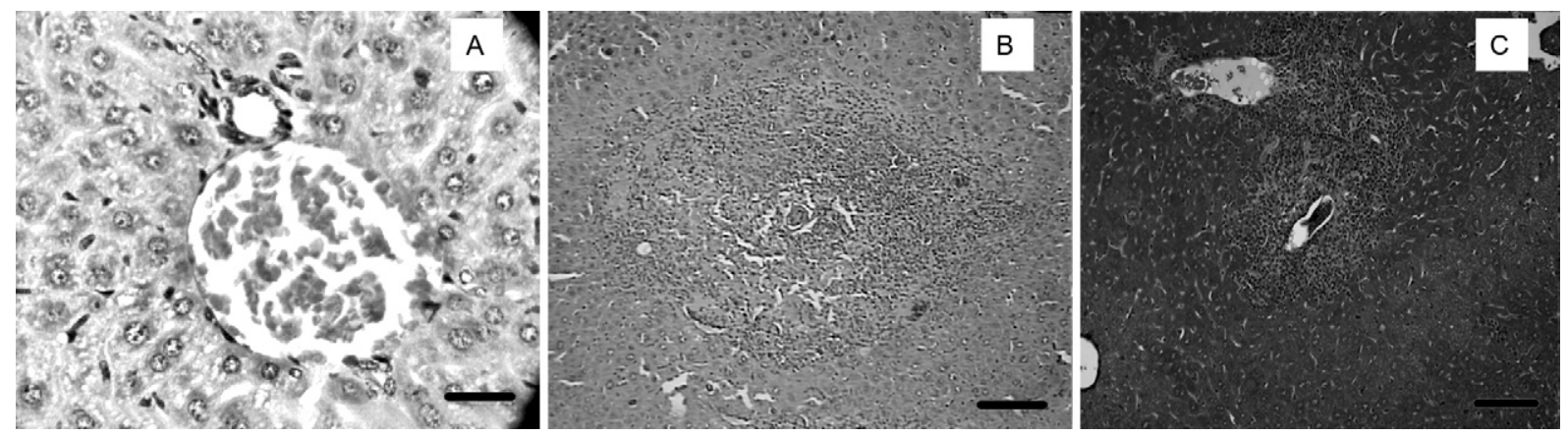

Fig. 2: histopathological analysis of liver sections from adult protein-restricted offspring. A: portal space and liver parenchyma (H\&E) (Bar $=10 \mu \mathrm{m})$; B: pre-granulomatous type granuloma characterized by intense acute inflammatory reaction $(\mathrm{H} \& \mathrm{E})(\mathrm{Bar}=20 \mu \mathrm{m})$; $\mathrm{C}:$ leukocyte migration encircling a central schistosomal egg (Masson's trichrome stain) $(\mathrm{Bar}=20 \mu \mathrm{m})$.

Here, for the first time, we evaluated the effects of S. mansoni infection in adult animals programmed by maternal undernutrition during lactation.

ICR offspring had lower body weight, food intake and total and VFM compared with uninfected CR. This suggests that infection influences the regulation of adiposity in obese mice. It has been shown that schistosomes are closely associated with lipid metabolism modulation (El Ridi et al. 2004, Tallima \& El Ridi 2005, Alencar et al. 2009). IPR offspring presented only lower total fat when compared with non-IPR offspring. These findings are probably related to the increased lipolysis caused by inflammation due to the higher energy demand of this process (catabolic effects).

ICR offspring showed a reduction in fat and this was reflected by lower serum leptin. Ob/ob (leptin-deficient) mice had lower hepatic fibrosis after 12 weeks of infection with S. mansoni (Potter \& Mezey 2002). ICR mice, which are probably hypoleptinaemic, likely have delayed development of hepatic fibrosis, despite the findings of the evaluation at nine weeks post-infection (acute phase). To confirm this possibility, other studies using a more advanced stage of infection are needed.

Some studies have shown that the host-parasite relationship can be modified by the nutritional status of the host. Thus, schistosome maturation (Kanuft \& Warren
1969), worm burden and oviposition reduction (Akpom 1982, Rocha 1982, Magalhães et al. 1986, Neves et al. 2001, Oliveira et al. 2001), as well as the production of altered eggs, have been observed in nutritionally restricted mice (Akpom \& Warren 1975). Our previous report showed that the pre-patent period and the kinetics of egg excretion were similar to well-fed controls (Simões et al. 2002).

The parasitological evaluations of adult offspring programmed by postnatal malnutrition showed that the prepatent period was longer than 45 days. This result confirms studies with undernourished mice, which showed a pre-patent period of 43 days (Simões et al. 2002). At 55 days post-infection with $S$. mansoni, PR offspring had a higher number of eggs in their faeces. Studies have suggested that protein deficiency during lactation leads to a deficiency in the tissue and mechanical barriers in the collagen, which facilitates the inflammatory reaction caused by $S$. mansoni in the intestinal mucosa that is necessary for the elimination of eggs in faeces (Costa \& Katz 1982, Costa et al. 1984, Lenzi et al. 1987, Machado e Silva et al. 1994). It is possible that programmed adult PR mice maintain the changes acquired during lactation and eliminate a greater number of eggs in the faeces as an adaptive strategy.

In the mesenteric vasculature, immature eggs require about five-six days for the embryo to differentiate and 

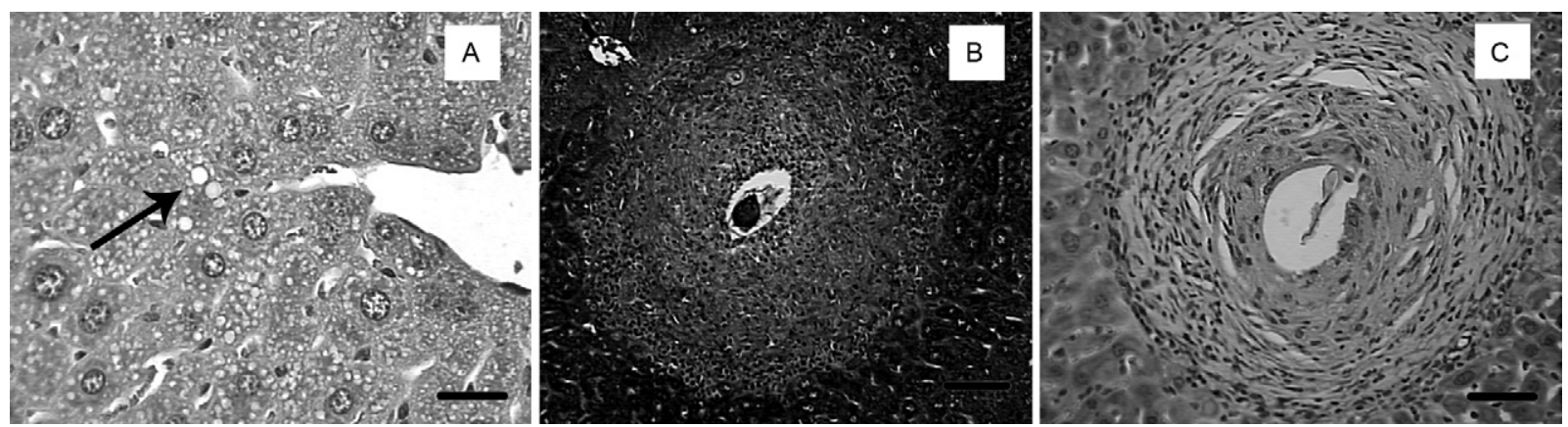

Fig. 3: photomicrographs of liver sections from adult caloric-restricted offspring. A: portal vein and microvesicular steatosis (arrow) and hepatocyte disclosing microvesicular steatosis $(\mathrm{H} \& \mathrm{E})(\mathrm{Bar}=10 \mu \mathrm{m})$; B: an exudative-productive granuloma $(\mathrm{H} \& \mathrm{E})(\mathrm{Bar}=20 \mu \mathrm{m})$; $\mathrm{C}: \mathrm{schistosomal}$ granuloma disclosing concentric arrangement of collagen fibers $(\mathrm{H} \& \mathrm{E})(\mathrm{Bar}=20 \mu \mathrm{m})$.

begin eliminating lytic and antigenic secretions through micropores in the eggshell (Andrade 2009). At this time, they cross the endothelial and mucosal barriers of the intestinal lumen, allowing mature eggs to reach the outside environment via the host's faeces. This process allows the eggs to exploit the host's cytokine production (Doenhoff et al. 1986, Lenzi et al. 1987, Brindley 2005).

In our study, all infected groups had higher numbers of immature eggs in the distal small intestine, which corroborates other studies (Costa \& Katz 1982, Machado e Silva et al. 1991, Martinez et al. 2003). Adult PR offspring had a higher total number of eggs in their faeces and intestinal portions, as well as a higher number of eggs in all stages of development.

Regarding infectivity, adult worms recovered in the C, CR and PR offspring were localised in the mesenteric and portal-veins. This result showed similarity with other studies using malnourished animals (Akpom 1982, Rocha 1982, Ferreira \& Coutinho 1999).

Schistosome eggs that do not pass through the intestinal mucosa are usually carried by the portal-vein blood flow to the liver, where they become trapped due to the insufficient diameter of the sinusoids (Pearce 2005). This process leads to inflammation, tissue eosinophilia, collagen deposition, fibrous expansion of the portal spaces and intra-hepatic portal-vein obstruction (Abath et al. 2006). Granuloma formation has been described as a two-stage process with a pre-granulomatous stage, characterised by a disorganised aggregation of cells, and a granulomatous stage, during which the cells become organised (Lenzi et al. 1998, 2006).

Infected offspring showed an increase in liver weight. This has been previously demonstrated in adult animals (Magalhães et al. 1986, Coutinho et al. 2003, Coutinho 2004 ) due to the inflammatory process caused by S. mansoni eggs (Mota \& Sleigh 1984, Sleigh et al. 1986). Liver pathology around mature eggs depends on, among other factors, the host nutritional status (Coutinho et al. 1997, Oliveira et al. 2004). Liver injury was moderate when compared with wellnourished control mice (Coutinho et al. 1997, 2003). However, the effects of schistosome parasitism on lactation are unknown.
The quantitative assessment of liver granulomas in the programmed group showed that PR offspring had a higher total number of granulomas. Qualitative analysis of liver granulomas sorted by exudation showed that PR offspring had more granulomas of the pre-granulomatous stage, whereas CR offspring had more exudativeproductive granulomas. Undernourished mice infected with $S$. mansoni were unable to produce periportal fibrosis in liver granuloma and it has been suggested that the nutritional status of the host contributes to the remodelling of liver granulomas during peri-ovular schistosomiasis (Coutinho 2004). One possible mechanistic explanation for the differences observed in liver morphology during Schistosoma infection concerns serum leptin levels. In the CR group, leptin is decreased with infection, whereas in the PR group there was no change. However, differences observed in the IPR offspring compared to the IC offspring could be related to differences in body weight.

IPR offspring, which showed lower body weight, had greater liver injury, as indicated by the increased number of areas altered by granulomatous exudative, as well as a decreased ability to produce collagen and higher inflammation due to the inability to modulate the inflammatory process. ICR offspring, which had higher adiposity but lower leptin levels, had a lower number of liver granulomas, increased production of collagen and several binucleate hepatocytes, thus providing better conditions for modulating the inflammatory response and regenerating the liver.

These findings indicate that the host-parasite relationship was more balanced. In conclusion, these observations suggest that protein or energy restriction during lactation has a prominent effect on the course of acute $S$. mansoni infection in adult offspring mice. It is known that leptin decreases the CRH-ACTH-corticosterone axis (Szücs et al. 2001) and cortisol decreases the inflammatory response necessary for granulomatous formation (Morales-Montor et al. 2001). In fact, ICR offspring displayed higher levels of serum corticosterone. Thus, ICR offspring that have inadequate levels of serum leptin may present a greater activation of the CRH-ACTH-corticosterone axis and, consequently, less-pronounced liver injury. 


\section{REFERENCES}

Abath FG, Morais CN, Montenegro CE, Wynn TA, Montenegro SM 2006. Immunopathogenic mechanisms in schistosomiasis: what can be learnt from human studies? Trends Parasitol 22: 85-91.

Ahima RS 2005. Central actions of adipocytes hormones. Trends Endocrinol Metab 16: 307-313.

Akpom CA 1982. Schistosomiasis: nutritional implications. Rev Infect Dis 4: 776-782.

Akpom CA, Warren KS 1975. Calorie and protein malnutrition in chronic murine schistosomiasis mansoni: effect on the parasite and the host. J Infect Dis 123: 6-14.

Alencar ACMB, Neves RH, Águila MB, Mandarim-de-Lacerda CA, Gomes DC, Machado-Silva JR 2009. High fat diet has a prominent effect upon the course of chronic schistosomiasis mansoni in mice. Mem Inst Oswaldo Cruz 104: 608-613.

Andrade ZA 2009. Schistosomiasis and liver fibrosis. Parasite Immunol 31: 656-663.

Assis AM, Barreto ML, Prado MS, Reis MG, Parraga IM, Blanton RE 1998. Schistosoma mansoni infection and nutritional status in schoolchildren: a randomized, double-blind trial in Northeastern Brazil. Am J Clin Nutr 68: 1247-1253.

Atinmo T, Mirmiran P, Oyewole OE, Belahsen R, Serra-Majem L 2009. Breaking the poverty/malnutrition cycle in Africa and the Middle East. Nutr Rev 67: 40-46.

Brindley PJ 2005. The molecular biology of schistosomes. Trends Parasitol 21: 533-536.

Buettner R, Schölmerich J, Bollheimer LC 2007. High-fat diets: modeling the metabolic disorders of human obesity in rodents. Obesity (Silver Spring) 15: 798-808.

Carmiel-Haggai M, Cederbaum AI, Nieto N 2005. A high-fat diet leads to the progression of non-alcoholic fatty liver disease in obese rats. Faseb J 19: 136-138.

Casapía M, Joseph SA, Núñez C, Rahme E, Gyorkos TW 2007. Parasite and maternal risk factors for malnutrition in preschool-age children in Belen, Peru using the new WHO Child Growth Standards. Br J Nutr 98: 1259-1266.

Costa MFFL, Katz N 1982. Comparative studies of Schistosoma mansoni strains isolated from patients with toxemic or intestinal forms of schistossomiasis. Am J Trop Med Hyg 31: 499-504.

Costa MFFL, Rocha RS, Katz N 1984. Comparative study of Schistosoma mansoni isolated from patients with hepatosplenic and intestinal clinical forms of schistosomiasis. Am J Trop Med Hyg 33: 918-923.

Costa-Silva M, Rodrigues-Silva R, Hulstijn M, Neves RH, de Souza Panasco M, Lenzi HL, Machado-Silva JR 2002. Natural Schistosoma mansoni infection in Nectomys squamipes: histopathological and morphometric analysis in comparison to experimentally infected $N$. squamipes and $\mathrm{C} 3 \mathrm{H} / \mathrm{He}$ mice. Mem Inst Oswaldo Cruz 97 (Suppl. I): 129-142.

Coutinho EM 2004. Malnutrition and hepatic fibrosis in murine schistosomiasis. Mem Inst Oswaldo Cruz 99 (Suppl. I): 85-92.

Coutinho EM, Abath FGC, Barbosa CS, Domingues ALC, Melo MCV, Montenegro SML, Lucena MAF, Romani SAM, Souza WV, Coutinho AD 1997. Factors involved in Schistosoma mansoni infection in rural areas of Northeast Brazil. Mem Inst Oswaldo Cruz 92: 707-715.

Coutinho EM, Abath FGC, Freitas LPCG, Salzano AC, Lapa MA, Campos FS, Melo EB 1991. Liver and serum soluble protein changes and pathomorphology in undernourished mice with acute schistosomiasis mansoni. Rev Soc Bras Med Trop 24: 235-243.
Coutinho EM, Barros AF, Barbosa Jr A, Oliveira SA, Silva LM, Araújo RE, Andrade ZA 2003. Host nutritional status as a contributory factor to the remodeling of schistosomal hepatic fibrosis. Mem Inst Oswaldo Cruz 98: 919-925.

Crompton DW, Nesheim MC 2002. Nutritional impact of intestinal helminthiasis during the human life cycle. Ann Rev Nutr 22: 35-59.

de Moura EG, Lisboa PC, Custódio CM, Nunes MT, Souza KP, Passos MCF 2007. Malnutrition during lactation changes growth hormone mRNA expression in the offspring at weaning and at adulthood. J Nutr Biochem 18: 134-139.

de Moura EG, Lisboa PC, Passos MCF 2008. Neonatal programming of euroimmunomodulation - role of adipocytokines and neuropeptides. Neuroimmunomodulation 15: 176-188.

Desai M, Crowther N, Ozanne SE, Lucas A, Hales CN 2000. Adult glucose and lipid metabolism may be programmed during fetal life. Biochem Soc Trans 23: 331-335.

Doenhoff MJ, Hassounah O, Murare H, Bain J, Lucas S 1986. The schistosome egg granuloma: immunopathology in the cause of host protection or parasite survival? Trans $R$ Soc Trop Med Hyg 80: 503-514.

Doenhoff MJ, Pearson S, Dunne DW, Lucas S, Bain J, Mussallam R, Hassounah O 1981. Immunological control of hepatotoxicity and parasite egg excretion in Schistosoma mansoni infections: stage specificity of the reactivity of the immune serum in T-cell deprived mice. Trans Royal Soc Trop Med Hyg 75: 41-53.

El Ridi R, Tallima H, Mohamed SH, Montash M 2004. Depletion of Schistosoma mansoni lung-stage schistosomula cholesterol by methyl-beta-cyclodextrin dramatically increases specific antibody binding to surface membrane antigens. J Parasitol 90: 727-732.

Erhuma A, Salter AM, Sculley DV, Langley-Evans SC, Bennett AJ 2007. Prenatal exposure to a low-protein diet programs disordered regulation of lipid metabolism in the aging rat. Am J Physiol Endocrinol Metab 292: 1702-1714.

Fagundes AT, Moura EG, Passos MC, Oliveira E, Toste FP, Bonomo IT, Trevenzoli IH, Garcia RM, Lisboa PC 2007. Maternal low-protein diet during lactation programmers' body composition and glucose homeostasis in the adult rat offspring. Br J Nutr 98: 922-928.

Fagundes ATS, Moura EG, Passos MCF, Santos-Silva AP, Oliveira E, Trevenzoli IH, Casimiro-Lopes G, Nogueira-Neto JF, Lisboa PC 2009. Temporal evaluation of body composition, glucose homeostasis and lipid profile of male rats programmed by maternal protein restriction during lactation. Horm Metab Res 41: 866-873.

Ferreira HS, Coutinho EM 1999. Should nutrition be considered as a supplementary measure in schistosomiais control? Ann Trop Med Parasitol 93: 437-447.

Freire N, Rodrigues-Silva R, Machado-Silva JR, Rey L 2003. A comparative parasitologic study on Biomphalaria glabrata snail and $\mathrm{C} 3 \mathrm{H} / \mathrm{He}$ mice infected with human and murine isolates of Schistosoma mansoni derived from Sumidouro, Rio de Janeiro, Brazil. Mem Inst Oswaldo Cruz 98: 783-787.

Godfrey KM, Barker DJ 2000. Fetal nutrition and adult disease. Am J Clin Nutr 71: 1344-1352.

Hughes S, Kelly P 2006. Interactions of malnutrition and immune impairment with specific reference to immunity against parasites. Parasite Immunol 28: 577-588.

Jardim-Botelho A, Brooker S, Geiger SM, Fleming F, Souza Lopes AC, Diemert DJ, Corrêa-Oliveira R, Bethony JM 2008. Age patterns in undernutrition and helminth infection in a rural area of Brazil: associations with ascariasis and hookworm. Trop Med Int Health 13: 458-467. 
Kanuft RF, Warren KS 1969. The effect of calorie and protein malnutrition on both the parasite and the host in acute murine schistosomiasis mansoni. J Infect Dis 120: 560-575.

Katz N, Chaves A, Pellegrino J 1972. A simple device for quantitative stool thick-smear technique in schistosomiasis mansoni. Rev Inst Med Trop Sao Paulo 14: 397-400.

Kristan DM 2002. Effects of intestinal nematodes during lactation: consequences for host morphology, physiology and offspring mass. J Exp Biol 205: 3955-3965.

Lennert K, Parwaresch MR 1978. Pathology of tissue mast cells. Verh Dtsch Ges Pathol 62: 546.

Lenzi HL, Kimmel E, Schechtman H, Pelajo-Machado M, Romanha WS, Pacheco RG, Mariano M, Lenzi JA 1998. Histoarchitecture of schistosomal granuloma development and involution: morphogenetic and biomechanical approaches. Mem Inst Oswaldo Cruz 93 (Suppl. I): 141-151.

Lenzi HL, Lenzi JA, Sobral AC 1987. Eosinophils favor the passage of eggs to the intestinal lumen in schistosomiasis. Braz J Med Biol Res 20: 433-435.

Lenzi HL, Romanha W de S, Zorzenon dos Santos RM, Rosas A, Mota EM, Manso PPA, Caputo LFG, Pelajo-Machado M 2006. Four whole-istic aspects of schistosome granuloma biology: fractal arrangement, internal regulation, autopoietic component and closure. Mem Inst Oswaldo Cruz 101 (Suppl. I): 219-231.

Li Hsü HF, Hsü JR, Davis GL 1972. Comparative studies on the lesions caused by eggs of Schistosoma japonicum and Schistosoma mansoni in livers of albino mice and rhesus monkeys. Ann Trop Med Parasitol 66: 89-97.

Lisboa PC, Fagundes AT, Denolato AT, Oliveira E, Bonomo IT, Alves SB, Curty FH, Passos MC, Moura EG 2008. Neonatal low-protein diet changes deiodinase activities and pituitary TSH response to TRH in adult rats. Exp Biol Med 233: 57-63.

Lisboa PC, Passos MC, Dutra SC, Santos RS, Bonomo IT, Cabanelas AP, Pazos-Moura CC, Moura EG 2003. Increased 5'-iodothyronine deiodinase activity is a maternal adaptive mechanism in response to protein restriction during lactation. J Endocrinol 177: 261-267.

Machado e Silva JR, Galvão C, Presgrave OAF, Rey L, Gomes DC 1994. Host-induced morphological changes of Schistosoma mansoni Sambon, 1907 male worms. Mem Inst Oswaldo Cruz 89: 411-414.

Machado e Silva JR, Oliveira RMF, Rodrigues-Silva R, Maldonado Jr A, Rey L 1991. Roedores silvestres como modelos experimentais da esquistossomose mansônica: Akodon arviculoides (Rodentia: Cricetidae). Rev Inst Med Trop Sao Paulo 33: 257-261.

Magalhães LA, Guaraldo AMA, Magalhães EMZ, Carvalho JF, Sgarbieri VC, Alcântara FG 1986. Esquistossomose mansônica em camundongos experimentalmente subnutridos. Rev Saude Publica 20: 362-368.

Marques CM, Motta VF, Torres TS, Aguila MB, Mandarim-de-Lacerda CA 2010. Beneficial effects of exercise training (treadmill) on insulin resistance and nonalcoholic fatty liver disease in highfat fed C57BL/6 mice. Braz J Med Biol Res 43: 467-475.

Marques RG, Morales MM, Petroianu A 2009. Brazilian law for scientific use of animals. Acta Cir Bras 24: 69-74.

Martinez EM, Neves RH, Oliveira RMF, Machado-Silva JR, Rey L 2003. Parasitological and morphological characteristics of Brazilian strains of Schistosoma mansoni in Mus musculus. Rev Soc Bras Med Trop 36: 557-564.

Morales-Montor J, Mohamed F, Ghaleb 2001. In vitro effects of hypothalamic-pituitary-adrenal axis (HPA) hormones on Schistosoma mansoni. J Parasitol 87: 1132-1139.
Mota E, Sleigh AC 1984. Water-contact patterns and Schistosoma mansoni infection in a rural community in Northeast Brazil. Rev Inst Med Trop 29: 230-235.

Moura EG, Lisboa PC, Custódio CM, Nunes MT, Souza KP, Passos MCF 2007. Malnutrition during lactation changes growth hormone mRNA expression in offspring at weaning and adulthood. J Nutr Biochem 18: 134-139.

Moura EG, Santos RS, Lisboa PC, Alves SB, Bonomo IT, Fagundes AT, Oliveira E, Passos MC 2008. Thyroid function and body weight programming by neonatal hyperthyroidism in rats - the role of leptin and deiodinase activities. Horm Metab Res 40: 1-7.

Muniz PT, Ferreira UM, Ferreira CS, Conde WL, Monteiro CA 2002. Intestinal parasitic infections in young children in São Paulo, Brazil: prevalence, temporal trends and associations with physical growth. Ann Trop Med Parasitol 96: 503-512.

Neves RH, Alencar ACMB, Aguila MB, Mandarim-de-Lacerda CA, Machado-Silva JR, Gomes DC 2007a. Light and confocal microscopic observations of adult Schistosoma mansoni from mice fed on a high-fat diet. $J$ Helminthol 81: 361-368.

Neves RH, Alencar ACMB, Costa-Silva M, Aguila MB, Mandarimde-Lacerda CA, Machado-Silva JR, Gomes DC 2007b. Longterm feeding a high-fat diet causes histological and parasitological effects on murine schistosomiasis mansoni outcome. Exp Parasitol 115: 324-332.

Neves RH, Machado-Silva JR, Pelajo-Machado M, Oliveira SA, Coutinho EM, Lenzi HL, Gomes DC 2001. Morphological aspects of Schistosoma mansoni adult worms isolated from nourished and undernourished mice: a comparative analysis by confocal laser scanning microscopy. Mem Inst Oswaldo Cruz 96: 1013-1016.

Normanton H, Houdijk JG, Jessop NS, Knox DP, Kyriazakis I 2007. The effects of changes in nutritional demand on gastrointestinal parasitism in lactating rats. Br J Nutr 97: 104-110.

Oliveira G, Rodrigues NB, Romanha AJ, Bahia D 2004. Genome and genomics of schistosomes. Can J Zool 82: 375-390.

Oliveira SA, Barbosa Jr AA, Gomes DC, Machado-Silva JR, Montarroyos V, Barros AF, Coutinho EM 2001. The morphology and morphometry of adult Schistosoma mansoni recovered from undernourished infected mice. Rev Soc Bras Med Trop 34: 157-158.

Ozanne SE, Hales N 2002. Early programming of glucose-insulin metabolism. Endocrinol Metab 13: 368-373.

Parraga IM, Assis AM, Prado MS, Barreto ML, Reis MG, King CH, Blanton RE 1996. Gender differences in growth of school-aged children with schistosomiasis and geohelminth infection. Am J Trop Med Hyg 55: 150-156.

Passos MCF, Ramos CF, Moura EG 2000. Short and long term effects of malnutrition in rats during lactation on the body weight of offspring. Nutr Res 20: 1603-1612.

Passos MCF, Vicente LL, Lisboa PC, Moura EG 2004. Absence of anorectic effect to acute peripheral leptin treatment in adult animals whose mothers were malnourished during lactation. Horm Metab Res 36: 625-629.

Pearce EJ 2005. Priming of the immune response by schistosome eggs. Parasite Immunol 27: 265-270.

Petry CJ, Dorling MW, Wang CL, Pawlak DB, Ozanne SE 2000. Catecholamine levels and receptor expression in low protein rat offspring. Diabet Med 17: 848-853.

Picard C, Lambotte L, Starkel P, Sempoux C, Saliez A, Van den Berge V, Horsmans Y 2002. Steatosis is not sufficient to cause an impaired regenerative response after partial hepatectomy in rats. J Hepatol 36: 645-652.

Plagemann A 2006. Perinatal nutrition and hormone-dependent programming of food intake. Horm Res 65: 83-89. 
Potter JJ, Mezey E 2002. Leptin deficiency reduces but does not eliminate the development of hepatic fibrosis in mice infected with Schistosoma mansoni. Liver 22: 173-177.

Rao MS, Papreddy K, Abecassis M, Hashimoto T 2001. Regeneration of liver with marked fatty change following partial hepatectomy in rats. Dig Dis Sci 46: 1821-1826.

Reeves PG, Nielsen FH, Fahey GC 1993. Ain-93 purified diets for laboratory rodents: final report of the American Institute of Nutrition ad hoc Writing Committee on the Reformulation of the Ain-76a Rodent Diet. J Nutr 123: 1939-1951.

Rocha H 1982. Schistosomiasis and malnutrition. Rev Infect Dis 4: 783-784.

Simões C, Neves RH, Barros LA, Brito PD, Cravo CO, de Moura EG, Machado-Silva JR 2002. Parasitological characteristics of Schistosoma mansoni infection in swiss mice with underlying malnutrition. Mem Inst Oswaldo Cruz 97 (Suppl. I): 143-147.

Sleigh AC, Hoff R, Mott KE, Maguire JH, da França Silva JT 1986. Manson's schistosomiasis in Brazil: 11-year evaluation of successful disease control with oxamniquine. Lancet 1: 635-637.

Souza-Mello V, Mandarim-de-Lacerda CA, Aguila MB 2007. Hepatic structural alteration in adult programmed offspring (severe maternal protein restriction) is aggravated by post-weaning highfat diet. BrJ Nutr 98: 1159-1169.
Stephenson LS, Latham MC, Ottesen EA 2000. Malnutrition and parasitic helminth infections. Parasitology 121 (Suppl.): S23-S38.

Szücs N, Varga I, Jakab C, Patócs A, Gláz E, Tóth M, Kiss R, Rácz $\mathrm{K}$ 2001. Leptin inhibits cortisol and corticosterone secretion in pathologic human adrenocortical cells. Pituitary 4: 71-77.

Tallima H, El Ridi R 2005. Methyl-beta-cyclodextrin treatment and filipin staining reveal the role of cholesterol in surface membrane antigen sequestration of Schistosoma mansoni and S. haematobium lung-stage larvae. J Parasitol 91: 720-725.

Vicente LL, Moura EG, Lisboa PC, Costa AMA, Amadeu T, Mandarim-de-Lacerda CA, Passos MCF 2004. Malnutrition during lactation is associated with higher expression of leptin receptor in pituitary of the adult offspring. Nutrition 20:924-928.

Vickers MH, Ikenasio BA, Breier BH 2001. IGF-I treatment reduces hyperphagia, obesity and hypertension in metabolic disorders induced by fetal programming. Endocrinol 142: 3964-3973.

WHO - World Health Organization 2005. Deworming for health and development. Report of the third global meeting of the partners for parasite control. Available from: whqlibdoc.who.int/hq/2005/ who_cds_cpe_pvc_2005.14.pdf.

Zhang BH, Weltman M, Farrell GC 1999. Does steatohepatitis impair liver regeneration? A study in a dietary model of non-alcoholic steatohepatitis in rats. J Gastroenterol Hepatol 14: 133-137. 